\title{
Effects of Livestock Grazing on Duck Nesting Habitat in Utah
}

\author{
Ben C. West ${ }^{1}$ and Terry A. Messmer ${ }^{2}$ \\ Authors are ${ }^{1}$ National Outreach Coordinator, The Berryman Institute, Mississippi State University, \\ Mississippi State, MS 39762-9690; and ${ }^{2}$ Professor, Department of Forestry, Range, and Wildlife, \\ Utah State University, Logan, UT 84341-5210.
}

\begin{abstract}
Periodic vegetation disturbance is an important yet controversial tool for waterfowl managers. Some have reported livestock grazing removes residual vegetation and thus is detrimental to nesting ducks, and others argue that such disturbance is necessary to maintain grassland health. We evaluated the impact of winter livestock grazing on duck nesting at Bear River Migratory Bird Refuge, Utah. During winter 1999, 6 experimental plots were grazed by cattle and 6 were ungrazed; in winter 2000, 8 plots were grazed and 8 were ungrazed. All grazing treatments were conducted during 15 November-15 March and averaged a stocking rate of 9.5 animal unit months/ha. During the following spring nesting season, we measured visual obstruction readings (VOR) on grazed and ungrazed sites. Although VOR on ungrazed sites were greater than those on grazed sites, this difference became less important as the nesting season progressed. Winter grazing impacted the nesting habitat of early-nesting ducks such as mallards (Anas platyrbynchos), but not that of late-nesting species such as cinnamon teal (Anas cyanoptera) and gadwall (Anas strepera). When using livestock grazing to manage grasslands, waterfowl managers should consider their management goals, the species composition of breeding duck populations, and environmental conditions.
\end{abstract}

\section{Resumen}

El disturbio periódico de la vegetación es una herramienta importante, pero controversial, para los manejadores de las áreas de hábitat de aves acuáticas. Algunos han reportado que el apacentamiento del ganado remueve la vegetación residual y que es prejudicial para el anidamiento de los patos, mientras que otros argumentan que tal disturbio es necesario para mantener la salud del pastizal. Evaluamos el impacto del apacentamiento del ganado en invierno sobre el anidamiento de los patos en el Refugio de Aves Migratorias Bear River, Utah. Durante el invierno de 1999, 6 parcelas experimentales fueron apacentadas por ganado y otras 6 no recibieron apacentamiento; en el invierno del 2000, 8 parcelas se apacentaron y otras 8 no; todos los tratamientos de apacentamiento se condujeron del 15 de Noviembre al 15 de Marzo con una carga promedio de 9.5 Unidades Animal Mes ha $^{-1}$. Durante la época de anidamiento en la siguiente primavera tomamos lecturas de la obstrucción visual (OVR) en los sitios apacentados y sin apacentar. Aunque las VOR de los sitios sin apacentar fueron mayores que las de los sitios apacentados, esta diferencia vino a ser menos importante conforme la estación de anidamiento progresó. El apacentamiento invernal impacto el hábitat de anidamiento de los patos que anidan temprano, como los "Mallard" (Anas platyrhynchos), pero no el de las especies que anidan más tarde, como el "Cinnamon teal” (Anas cyanoptera) y el "Gadwall” (Anas strepera). Cuando se utiliza el apacentamiento del ganado para manejar el pastizal, los manejadores de las áreas de anidamiento de aves acuáticas deben considerar en sus metas de manejo la composición de especies de las poblaciones de patos en reproducción y las condiciones ambientales.

\section{INTRODUCTION}

Periodic vegetation disturbance benefits grassland systems. Disturbances can increase forage production, increase photosynthetic rate, reduce plant water stress, accelerate nutrient cycling (Hart and Norton 1988) and encourage species richness (Hobbs and Huenneke 1992). Compared to other disturbance tools, livestock grazing offers many advantages, including low liability and cost, ability to generate income, and flexibility in intensity of application.

Research was funded by the US Fish and Wildlife Service, Fish and Wildlife Foundation, Utah State University Quinney Professorship for Wildlife Conflict Management, and the Berryman Institute.

At the time of research, the senior author was research assistant, Department of Fisheries and Wildlife, Utah State University, Logan, UT 84341-5210.

Correspondence: Ben C. West, Dept of Wildlife and Fisheries, Box 9690, Mississippi State University, Mississippi, MS 39762. Email: benw@cfr.msstate.edu

Manuscript received 8 July 2005; manuscript accepted 19 December 2005.
Dabbling ducks are elastic in their selection of nesting areas (Johnson and Grier 1988), but most require some nesting cover (Bellrose 1980). Some have argued that livestock grazing reduces nesting cover and hinders duck nesting (Kirsch et al. 1978), whereas others contend that grazing can benefit duck nesting habitat (Kaiser et al. 1979). In instances where livestock grazing and duck production are co-objectives, rotational grazing systems are superior to continuous grazing (Lapointe et al. 2000). Where duck production is the sole objective, however, the value of livestock grazing is still in debate (Kirby et al. 1992). Our objective was to assess the impact of a winter livestock grazing program on duck nesting habitat in Utah.

\section{MATERIALS AND METHODS}

This study was conducted on the Grasslands Management Unit (GMU) of the Bear River Migratory Bird Refuge (BRMBR), Utah (lat $41^{\circ} 27^{\prime} \mathrm{N}$, long $112^{\circ} 3^{\prime} \mathrm{W}$ ). This unit is comprised of 


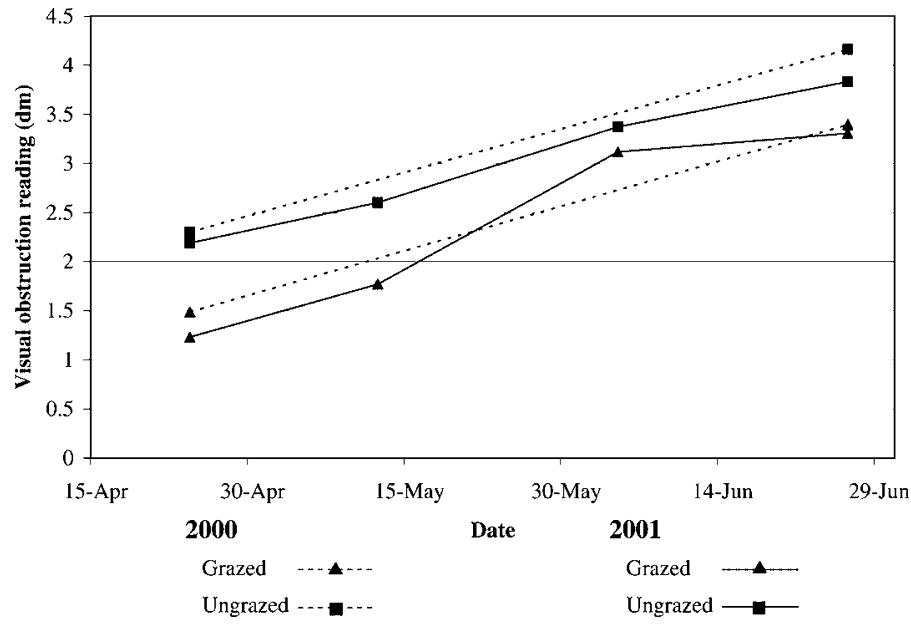

Figure 1. Average visual obstruction readings (VOR) taken on experimental plots (6-8 ha) grazed by livestock during the prior winter as compared to ungrazed plots on Bear River Migratory Bird Refuge, Utah, 2000-2001. Averages in 2000 are based on 6 experimental plots (3 grazed, 3 ungrazed) measured during 2 sampling periods; averages in 2001 are based on 16 experimental plots (8 grazed, 8 ungrazed) measured during 4 sampling periods.

upland and wet meadow habitats dominated by grasses (Agropyron sp.), sedges (Carex sp.), and rushes (Juncus sp.) interspersed with emergent wetlands. BRMBR developed and implemented a short-duration, high-intensity, winter (15 November-15 March) cattle grazing program on this area in 1995.

\section{Grazing Treatments on Study Plots}

We randomly located 6 plots (12-15 ha in size) on the GMU prior to the winter of 1999; as part of a larger study, 3 of these plots were surrounded by a predator exclosure, whereas the remaining 3 were not (West 2002). Grazing treatments were conducted during the winters of 1998-2000, with all plots being grazed during the winter of 1998 to establish baseline conditions. During winter 1999, we split each plot into halves and conducted a grazing treatment on a randomly selected half plot. We used a temporary, single-strand electric fence to facilitate the grazing treatments. To offset any potential differences in habitat or other influences between the half plots, we switched the treatments during winter 2000; the half plots that were grazed during 1999 were rested in 2000 and vice versa. In 1999, an additional 2 plots were added to the study, both of which were grazed during winter 1999. Subsequently, we randomly selected half of each plot to be grazed during winter 2000. Thus, during the 2000 nesting season, we collected data on 6 grazed and 6 ungrazed half plots. During the 2001 nesting season, we collected data for 8 grazed and 8 ungrazed half plots.

The grazing treatments were implemented with the use of cows and cow/calf pairs between 15 November and 15 March and lasted $\leq 46$ days. Cattle were removed from the plots when, by visual estimation, $80 \%$ of the residual vegetation was removed. The average stocking density for the half plots was 8.6 animal units (AU)/ha during 1999 and 15.5 AU/ha during winter 2000. Average stocking rates were 8.7 animal unit months (AUM)/ha in 1999 and 10.3 AUM/ha in 2000.

\section{Data Collection}

Vegetation Response. To measure the growth response of vegetation within grazed and rested sites, we collected visual obstruction readings (VOR) in each half-plot using a Robel pole (Robel et al. 1970). In each half-plot, we collected VOR at 20 random locations during each sampling period. To identify sampling locations, we selected 4 points distributed evenly throughout each half-plot and collected VOR at 5 points located at a random distance and direction away. During spring 2000, we collected VOR during 2 sampling periods: before spring green-up and at the conclusion of the nesting season (in early May and late June, respectively), and only for those plots surrounded by predator exclosures. Thus, in 2000, we collected VOR on 3 grazing treatments and 3 controls over 2 sampling periods. In spring 2001, we collected VOR during 4 sampling periods: once prior to spring green-up and once following each round of nest searching. We collected these measurements on each plot, thus resulting in measurements for 8 grazing treatments and 8 controls.

Nest Searches. We conducted 3 nest searches during midMay, early June, and late June during the spring of 1999-2001, with the use of 2 vehicles and a drag chain (Klett et al. 1986). After finding a nest, we collected standard information (i.e., number of eggs, incubation stage, etc.) and noted whether the nest was located in a grazed or ungrazed plot. We measured the VOR at each nest site using a Robel pole (Robel et al. 1970).

\section{Data Analysis}

We considered all inferential tests with $P$ less than 0.1 as statistically significant. To test for differences in VOR readings between grazed and ungrazed half plots, and across sampling periods, we used a one-way analysis of variance (ANOVA) with repeated measures. To predict the average VOR of available nest sites within each plot at the time each nest was found, we pooled random VOR measurements for each plot and period. Using those averages, we interpolated the average VOR measurement per plot on the day each nest was found. We computed the difference between that day's interpolated average VOR and that measured at each nest and used a one-sample $t$ test to determine if these differences were $=0$.

\section{RESULTS}

\section{Grazing Treatments and Vegetative Response}

During the 2000 nesting season, VOR measurements did not differ between grazed and ungrazed sites $\left(F_{1,4}=3.32\right.$, $P=0.11$ ) (Fig. 1). There was no interaction between period and grazing treatment for the 2000 nesting season $\left(F_{1,4}=0.25\right.$, $P=0.65)$. During the 2001 nesting season, VOR readings were greater on ungrazed plots $\left(F_{1,14}=13.36, P<0.01\right)$, and no interaction occurred between period and grazing treatment $\left(F_{3,42}=1.31, P=0.28\right)$.

\section{Duck Nesting}

Nesting Data. During 1999-2001, we located and monitored 50 duck nests. Cinnamon teal nests (Anas cyanoptera) accounted for a majority of the nests found $(74 \%, n=37)$, 
Table 1. Number of duck nests found on experimental plots (6-8 ha) located on Bear River Migratory Bird Refuge, Utah, 2000-2001. In 2000, 6 plots were grazed by domestic livestock the previous winter and 6 were rested. In 2001, 8 plots were grazed by domestic livestock the previous winter and 8 were rested.

\begin{tabular}{ccccccccc}
\hline & \multicolumn{2}{c}{ Cinnamon teal } & & \multicolumn{2}{c}{ Gadwall } & & \multicolumn{2}{c}{ Mallard } \\
\cline { 2 - 3 } \cline { 8 - 9 } \cline { 8 - 9 } Year & Grazed & Ungrazed & & Grazed & Ungrazed & & Grazed & Ungrazed \\
\hline 2000 & 8 & 4 & & 0 & 0 & & 1 & 2 \\
2001 & 6 & 7 & & 1 & 1 & & 0 & 1 \\
Total & 14 & 11 & & 1 & 1 & & 1 & 3 \\
\hline
\end{tabular}

followed by gadwall (Anas strepera) $(18 \%, n=9)$ and mallard (Anas platyrhynchos) $(8 \%, n=4)$ nests (Table 1). The average nest initiation date was different for the 3 nesting species; mallards nested earliest ( 7 May \pm 9 days), followed by cinnamon teal (29 May \pm 3 days) and gadwall (9 June \pm 6 days) $\left(F_{2,47}=4.43, P=0.02\right)$.

Site Preference. We found little evidence that grazing influenced hens' choice of nest sites (Table 1). In 2000, more nests were located in grazed half plots and in 2001 more were located in ungrazed half plots, but over the duration of the study, the number of hens nesting in grazed half plots $(n=16)$ was similar to that nesting in ungrazed half plots $(n=15)$.

Considering all nests found during 1999-2001, cinnamon teal nested at sites with the lowest $\operatorname{VOR}(\bar{x}=3.4, \mathrm{SE}=0.21)$; mallards $(\bar{x}=4.4, \quad \mathrm{SE}=0.51)$ and gadwall $(\bar{x}=5.1$, $\mathrm{SE}=0.52)$ nested at sites with higher $\operatorname{VOR}\left(F_{2,47}=6.27\right.$, $P<0.01$ ). For all nests 2000-2001, the difference between VOR measurements at the nest and predicted average VOR measurements at random points was $>0\left(\bar{x}_{\text {difference }}=0.67 \mathrm{dm}\right.$, $\left.t_{31}=3.1, P<0.01\right)$. This difference existed for mallard nests $\left(\bar{x}_{\text {difference }}=1.73 \mathrm{dm}, t_{3}=3.1, P=0.02\right)$, but not for cinnamon teal $\left(\bar{x}_{\text {difference }}=0.36 \mathrm{dm}, t_{24}=1.6, P=0.12\right)$; too few gadwall nests were found for inferential tests.

\section{DISCUSSION}

That predator fences existed around half of the plots was a potential factor in these data analyses; however, the fences were completely ineffective at excluding predators and thus did not represent a treatment effect (West 2002). Thus, we did not consider the predator fences in the interpretation of these data.

Mallards, gadwall, and cinnamon teal prefer different habitat types (Bellrose 1980), but the small number of nests we located hampered our ability to evaluate these differences in relation to the livestock grazing program at BRMBR. Drought conditions persisted on BRMBR during 2000 and 2001, resulting in low breeding populations and nesting effort. Moreover, plots on the GMU grazed by domestic livestock during the winter had less residual cover as compared to control plots, but drought conditions likely hampered the recovery of grazed vegetation. Nevertheless, this research describes conditions in dry years, a worst-case scenario.

Managed grazing systems (e.g., rest rotation, short duration) are superior to continuous livestock grazing when duck production is the primary management objective (Lapointe et al. 2000). Any livestock grazing that reduces residual vegetation,

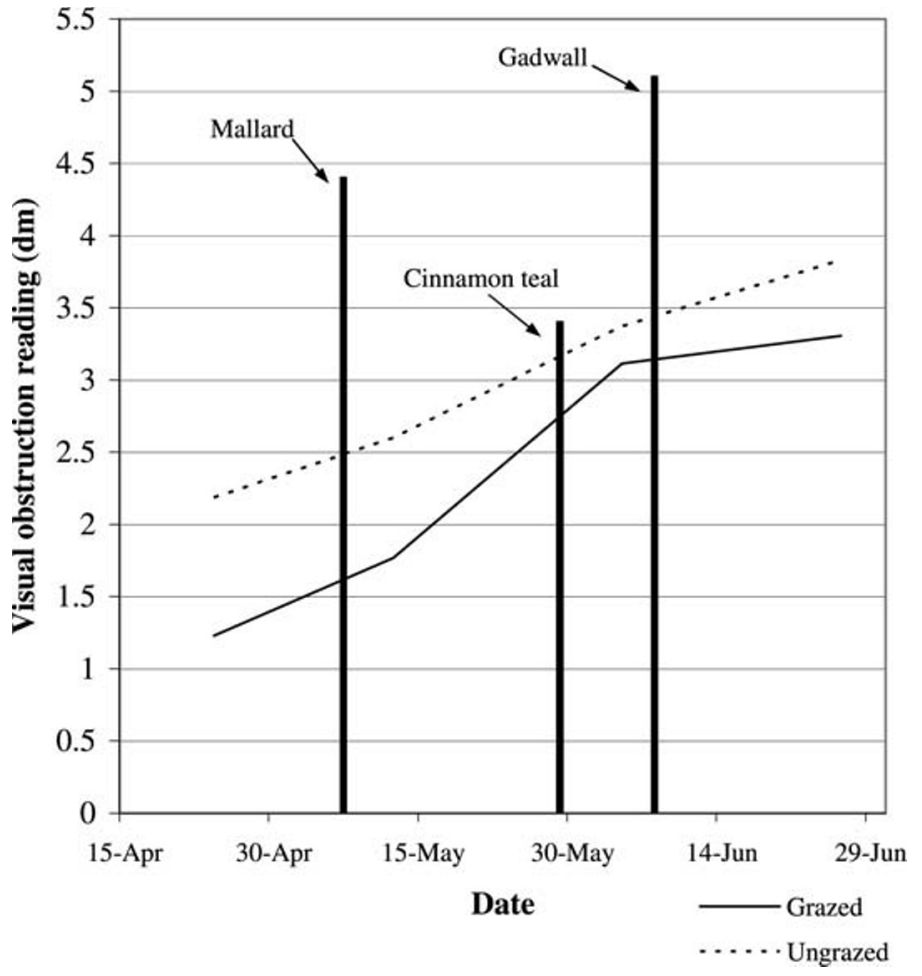

Figure 2. Average visual obstruction readings (VOR) taken on experimental plots (6-8 ha) either grazed by livestock or not grazed during the prior winter, as compared to average date of nest initiation and average VOR at the nest of 3 species of dabbling ducks on Bear River Migratory Bird Refuge, Utah, 1999-2001. Vertical bars are located on the $x$ axis to indicate average date of nest initiation for each species, and on the $y$ axis to indicate average VOR measurements at the nest for each species.

even when carefully managed, can be somewhat detrimental to nesting ducks (Kirsch 1969; Kirsch et al. 1978; Kruse and Bowen 1996). Yet most prior studies were conducted on areas where the primary nester was mallards, which requires relatively tall nesting cover early in the spring (Bellrose 1980). Other duck species may nest later in the year or prefer less vegetative cover, thus diminishing the impact of grazing on nesting habitat.

Comparing duck species' VOR preferences with average conditions at the time of nest initiation is enlightening (Fig. 2). Because mallards nested early and preferred tall vegetation, residual cover is crucial for this species. In early spring, only ungrazed sites averaged $>2 \mathrm{dm}$, the minimum required for early-nesting mallards (Baldassarre and Bolen 1994). Peak nest initiation for gadwall occurred later in the spring, when VOR measurements on grazed and ungrazed sites both averaged $>2.5 \mathrm{dm}$, which is adequate nesting cover for this species (Kruse and Bowen 1996). Similarly, because cinnamon teal nested later in the spring, both grazed and ungrazed plots offered suitable nesting cover during peak nest initiation.

\section{MANAGEMENT IMPLICATIONS}

The winter livestock grazing program at BRMBR had no negative impact on cinnamon teal or gadwall nesting habitat, but possibly did so for mallards. This may be unimportant, however, because BRMBR is a relatively unimportant production 
area for mallards, but highly important for cinnamon teal, a species of special concern (US Fish and Wildlife Service 1997).

However, if BRMBR managers wish to better manage nesting habitat for mallards, they should consider implementing a rotational grazing system to preserve some undisturbed residual nesting cover early in the spring.

Some have argued that generalizations about the impact of grazing on duck nesting habitat are tenuous because of poor study designs and site-specific variation in management parameters (Holechek et al. 1982). Accordingly, this study evaluated a specific grazing system, local habitat, and nesting population and thus may not pertain to different areas. However, in areas with late-nesting ducks and relatively early springs, a winter livestock grazing program is a potentially valuable management tool.

\section{ACKNOWLEDGMENTS}

We thank all BRMBR personnel for their support and dedication to this project.

\section{LITERATURE CITED}

Baldassarre, G. A., and E. G. Bolen. 1994. Waterfowl ecology and management. New York, NY: Wiley. 632 p.

Bellrose, F. C. 1980. Ducks, geese and swans of North America. Harrisburg, PA: Stackpole Books. 540 p.

HaRT, R. H., and B. E. Norton. 1988. Grazing management and vegetation response. In: P. T. Tueller [ED.]. Vegetation science applications for rangeland analysis and management. Norwell, MA: Kluwer Academic. p 493-526.

HobBs, R. J., AND L. F. Huenneke. 1992. Disturbance, diversity, and invasion: implications for conservation. Conservation Biology 6:324-337.

Holechek, J. L., R. Valdez, S. D. Schemnitz, R. D. Pieper, and C. A. Davis. 1982. Manipulation of grazing to improve or maintain wildlife habitat. Wildlife Society Bulletin 10:204-210.
Johnson, D. H., AND J. W. Grier. 1988. Determinants of breeding distributions of ducks. Wildlife Monographs 100.

Kaiser, P. H., S. S. Berlinger, and L. H. Fredrickson. 1979. Response of blue-winged teal to range management on waterfowl production areas in Southeastern South Dakota. Journal of Range Management 32: 295-298.

Kirby, R. E., J. K. Ringelman, D. R. Anderson, and R. S. Sojda. 1992. Grazing on national wildlife refuges: do the needs outweigh the problems? Transactions of the North American Wildlife and Natural Resources Conference 57: 611-626.

KIRSCH, L. M. 1969. Waterfowl in relation to grazing. Journal of Wildlife Management 33:821-828.

KIRSCH, L. M., H. F. DuebBert, And A. D. KRuSE. 1978. Grazing and haying effects on habitats of upland nesting birds. Transactions of the North American Wildlife and Natural Resources Conference 43:486-497.

Klett, A. T., H. F. Duebbert, C. A. Faanes, and K. F. Higgins. 1986. Techniques for studying nest success of ducks in upland habitats of the Prairie Pothole Region. Publication 158. Jamestown, ND: US Fish and Wildlife Service Resource. 22 p.

Kruse, A. D., And B. S. Bowen. 1996. Effects of grazing and burning on densities and habitats of breeding ducks in North Dakota. Journal of Wildlife Management 60:233-246.

Lapointe, S., J. F. Giroux, L. Belanger, and B. Filion. 2000. Benefits of rotational grazing and dense nesting cover for island-nesting waterfowl in southern Quebec. Agriculture, Ecosystems, and Environment 78:261-272.

Robel, R. J., J. N. Briggs, A. D. Dayton, and L. C. Hulbert. 1970. Relationships between visual obstruction measurements and weight of grassland vegetation. Journal of Range Management 23:295-297.

US FiSh and WildLIfE Service. 1997. Bear River Migratory Bird Refuge comprehensive management plan. Denver, CO: US Fish and Wildlife Service, Division of Refuges and Wildlife, Region 6. 41 p.

WEST, B. C. 2002. The influence of predator exclosures and livestock grazing on duck production at Bear River Migratory Bird Refuge, Utah [dissertation]. Logan, UT: Utah State University. $151 \mathrm{p}$. 